\title{
HIGHER EDUCATION STUDY PROGRAMME QUALITY ASSESSMENT
}

\author{
Ludmila BandevičA ${ }^{1}$, Agnese Līgotne² \\ University of Latvia (Latvia)
}

\begin{abstract}
Study programme quality assessment provides higher education quality which in its turn is an essential precondition for the successful national economy development. At the moment the society has a lot of discussion about what is higher education quality and how to assess it. The pragmatic approach makes us set criteria for study programme quality assessment. However, before doing that one must understand what higher education quality is. Developing over the years, higher education has created different quality understandings. The different quality understandings form the necessity of different quality assessment approaches. As the foundation of higher education quality assessment to create the methodological basis there are taken higher education quality assessment conceptions distinguished by R. Barnett: objective, subjective and development. Each of the conceptions intends to use different approaches for higher education assessment. The research approbates the usage of The Analytic Hierarchy process (AHP) method to detect the most significant study programme quality criteria and the most suitable way of assessment for them. AHP method is based on expert surveys, which were taken part by two most important interest groups interested in higher education: higher education administrative staff and students. Higher education administrators are represented by Higher Education Council representative, LU heads of administrative departments and leadership staff who are responsible for study quality and programme accreditation. In their turn, students are represented by members of Latvian Student Association, LU student council representatives and students from
\end{abstract} different LU faculties.

KEY WORDS: study programme quality, quality assessment methodology, assessment criteria, approaches for quality assessment, the Analytic Hierarchy Process method.

JEL CODES: I230, I210, D790

\section{Introduction}

Traditionally the notion of "quality" in higher education was integrated into academic life; it was considered as self evident and accepted for everyone. Quality was connected with academic freedom and was rooted deeply into academic traditions. State regulations, for example, the necessity of having the Doctor's degree, were set with the aim to provide the quality of academic work and knowledge. Together with that academic environment did not need the necessity of defining the notion of "quality" or discuss its significance. There was an opinion that higher education can be discussed only by academicians who are professionals in this field; therefore quality provision and development in higher education were left under their management. The notion "quality" in higher education was something like untold knowledge, which included in

1 Ludmila Bandeviča - University of Latvia, Faculty of Economic and Management, Prof. Dr. habil. oec., Scientific interest: mathematical modelling in economics and management.

E-mail: ludmila.bandevica@1u.lv

Tel.: +371 67034753 .

2 Agnese Līgotne - University of Latvia, Faculty of Education, Psychology and Art, Doctoral student, Scientific interest: Quality of Higher Education Study Programme.

E-mail: agnese.ligotne@lu.lv

Tel.: +37167034348 
itself both what the quality is, and how to provide it. Hungarian and British erudite Polanyi characterizes it as silent knowledge: "Know more than say" (Polanyi, 1966: 22-24).

We can see two main problems which complicate the definition of "higher education quality" notion:

Problem No. 1: Quality notion in higher education is a lot more specific and complicated than in other fields, because higher education aims are different, and also its members cannot be unequivocally compared to business or state sector fields;

Problem No. 2: The differences of understanding the notion of "higher education quality" appear depending on which perspective of higher education interested side to look at it. It is promoted by both different needs of interested sides and non-uniformity of higher education;

While studying the research literature about quality assessment, we can identify three main fields where are set quality standards and assessment criteria: state sector organizations, industrial and service providing companies. But higher education cannot be directly (without additional conditions) included into any of these fields, because its aims and tasks are different. Higher education does not have clients, but it has interested sides. The quality notion in higher education is a lot more discussed and specific than it is in other fields. In industrial and service companies the quality is oriented to client satisfaction and process. Many people associate the presumptions about higher education quality with academic values which not always are oriented to the satisfaction of students' needs; therefore higher education is quite often reproached for insufficient quality. However, on the other side, in the author's opinion, not only higher education establishments, but also student himself is responsible for the quality of acquired knowledge and skills.

Higher education quality can be looked at from different perspectives, which in their turn form different understanding about that. Also, Swedish researcher Giertz stresses that when defining the notion of "higher education quality" and comparing it with other people's understanding of higher education quality, there more likely are going to be bigger or smaller differences (Giertz, 2000: 296-300). We can distinguish two way reasons for the different understanding of "quality" notion. Firstly, the interested sides in higher education quality are not only the academic staff and students, but also parents, employers, state and society on the whole. British researcher Barnett stresses the different aims and interests of the interested sides, which cannot always be combined or united, therefore each of the interested sides prefer different quality aspects (Barnett, 1992: 31-34). Secondly, a different understanding promoting factor is non-uniformity of higher education. Developing over the years, higher education has created different forms - professional and academic higher education. It is implemented not only by state universities, but also by state and private higher education establishments, colleges. Also the higher education levels are different: college level, basic studies and higher level studies. We must take into account that this diversity creates different aims and purposes for higher education. As well, labour market understanding about non-uniformity of higher education creates satisfaction with higher education on the whole. It was proved by the study done by Norwegian researchers Storen and Aamodt about employment and higher education quality (Storen \& Aamodt, 2010: 311-312).

Assessing the higher education quality we must take into account all the definition problems of the "higher education quality" notion mentioned above. There arises the question who has to decide, which of the aspects should be included or which should be given priority or first hand in quality concept? There is an impression that the question is about power and influence. We can agree with British academician Ball, that, when defining what higher education quality is, we have to come into contact with political aspects as well (Ball, 1985: 103).

One of the main questions of discussion is ,higher education usefulness to society”, should it be included into higher education quality understanding. Swedish authors do not support the inclusion of this aspect into higher education quality definition, because he considers that academic quality is not usefulness to society. Swedish researcher and practitioner Van Vught distinguishes two ways quality of higher education: outer or inessential, and inner or essential (Vught, 1997: 80-81). The outer quality is considered by the researcher as inessential, as it characterizes the ability of higher education establishments to react to the changing society needs, taking into account, that it is a part of society. In its turn, the inner quality is considered by the author as essential, as it characterizes main values in higher education "unconnected search for truth and justice, as 
well as altruistic pursuit for knowledge", therefore with this in this understanding "higher education usefulness to society" becomes secondary.

The purpose for this article is to make a methodological foundation for higher education study programme quality assessment and assess significance of higher education alternative approaches using the AHP method.

Dawn for this research created by Briška (Briška (today Līgotne), 2010: 132-133). Author used quality understandings grouped by Harvey and Green and higher education quality assessment conceptions subdivided by Barnett for characterize a quality of study programme (Barnett, 1992; Harvey, Green, 1993). In this paper quality understandings and assessment concepts mentioned above transform to assessment methodology for study programme quality. According to theoretical background, there are three alternative approaches for assessing quality of study programme: experts' assessment, quantitative indicators and students' assessment. Authors used expert survey and the AHP method for evaluating these alternative assessment approaches.

\section{Formation of higher education quality assessment methodological foundation}

British researchers Harvey and Green distinguish quality understandings, determining what? and how? should be done to ensure and assess higher education quality (Harvey, Green, 1993: 3). Researchers distinguish five quality understanding perceptions:

- quality as exception;

- quality as excellence;

- quality as correspondence to aim;

- quality as financial value;

- quality as transformation.

Looking through L. Harvey and D. Green's grouped quality understanding perceptions, we can state that quality understandings differ not only in their wideness, but also in their purpose. Depending on the way of quality, the aims of understandings change, that is, the inner quality understanding concentrates on higher education process quality provision, but the outer quality understanding - on result provision. This division can be proved by that for the interested sides in higher education more acceptable and understandable there seems the quality which is concerned to higher education results, that determine the inclusion of higher education usefulness to society as the characterizing indicator in higher education assessment (Vught - outer quality). Higher education quality ways and understanding perceptions mentioned above have been summarised in Figure 1.

The different understandings about higher education quality determine the necessity for different quality assessment approaches. British academician Barnett distinguishes three higher education quality assessment conceptions: objective, subjective and development (Barnett, 1992: 45-52). Objective and subjective quality assessment conceptions are suitable for the assessment of outer higher education assessment, as they assess the acquired result. 


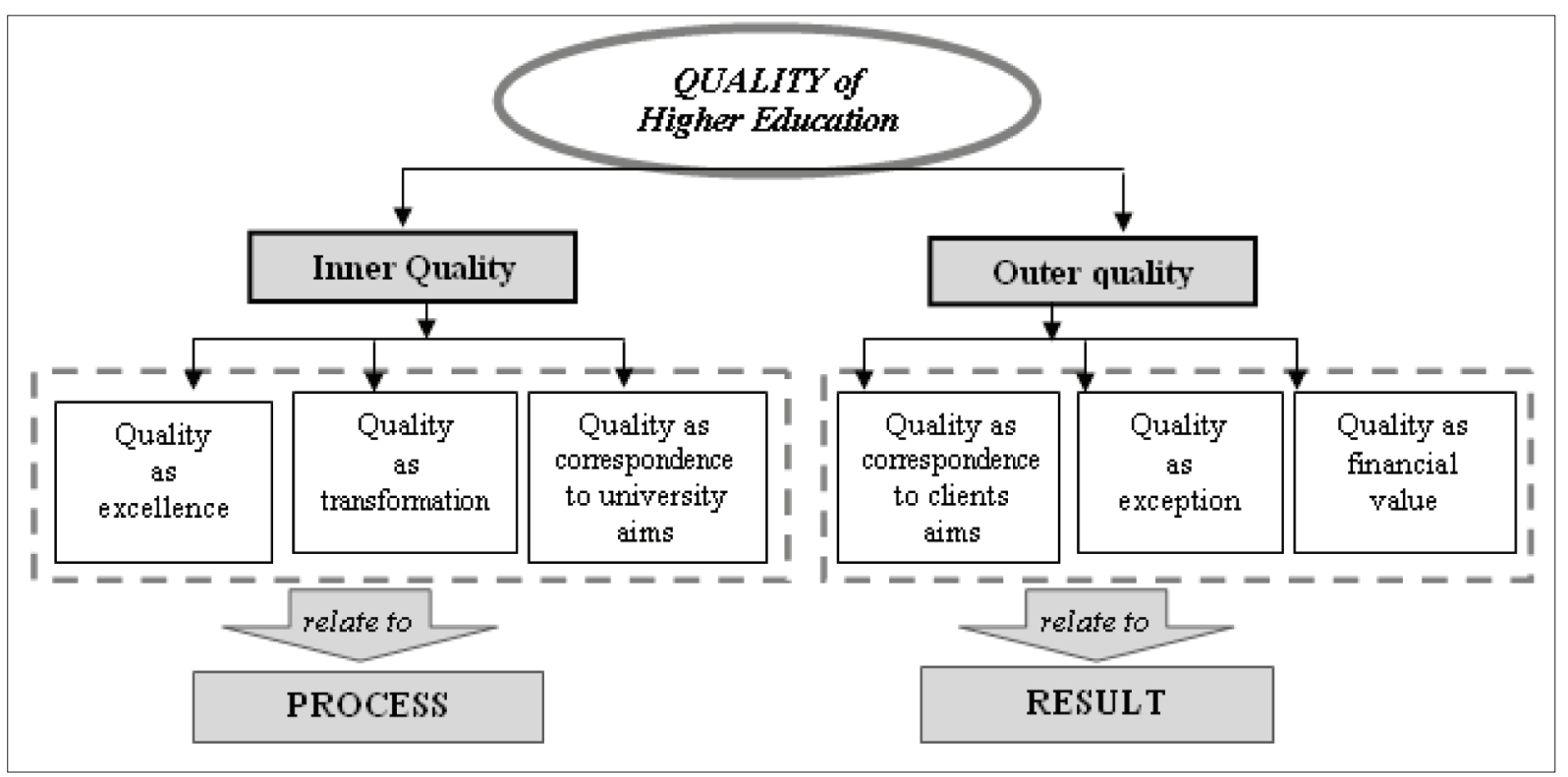

Figure 1. Perceptions for quality in higher education Source: created by authors

Objective quality assessment conception determines mostly the usage of quantitative measurements in education quality assessment. Usually this quality assessment conception is used when assessing the input and results of education system. It characterizes the perception of quality as exception, where the main attention is paid to the quality of input, which is considered as a guarantee for getting qualitative results. In its turn, to use study process results characterizing indicators in higher education quality assessment is intended by the perception quality as financial value. When assessing higher education quality, it is very important to ensure the objectiveness of the acquired assessments, which can be the most precisely provided by quantitative characterizing indicators. However, to compare the acquired assessments mutually, and as a result of that, to make decisions about education quality in one or another higher education establishment, or study programme, there should be carefully selected assessment criteria, as quite often the selection of criteria determines the acquirable result. The similar observation had professor Rauhvarger about university ranking indicators (Rauhvargers, 2011: 13).

Subjective quality assessment conception does not determine absolute usage of criteria, but it makes to assess higher education correspondence to aims. Anything in higher education quality is assessed in connection with aim; therefore the stress should be put on the quality assessment of different interested sides in higher education. This assessment corresponds to the perception quality as correspondence to (clients) aim, besides, when assessing higher education quality from client's perspectives, there should definitely be used students' assessment about study quality. Students are involved in the creation of higher education results; therefore they are most closely connected with study programme quality.

To assess higher education inner quality, R. Barnett offers development conception, where there has been assessed the sustainability of higher education establishment or study programme. Its aim is to assess the opportunities of development, taking into consideration the existing situation. The main difference from the objective and subjective conceptions is concentration on the inner quality, not taking into account ,higher education usefulness to society". Assessment involves only students and university academic staff who determines what should be done to improve higher education quality. Development conception is suitable for higher education quality understandings which refer to the process and the provision of inner higher education provision: quality as excellence, quality as transformation and quality as correspondence to (universi- 
ty) aim. The authors consider that one of the main elements of the development conception is self-assessment and SWOT analysis which provides quality improvement and sustainability.

Each of the conceptions intends to use different quality assessment alternative approaches. Objective conception determines the usage of quantitative indicators in higher education study programme quality assessment, but subjective conception - surveys of students and other interested sides. In its turn development conception as the most suitable one mention the self-assessment which can be compared to inner experts' assessment.

To assess the significance of higher education quality assessment alternatives according to the three conceptions discussed above, there will be used the Analytic Hierarchy process method (AHP). This method is suitable for solving this kind of unique cases not only to assess the significance of the mentioned alternatives, but also to detect the most important criteria to assess study programme quality.

\section{Basic guidelines of using the Analytic Hierarchy process method}

Traditionally, when assessing higher education or study programme quality, there are distinguished three assessment aspects: first, input to ensure the study process or "available resources", second, study environment and process organization, and third, students' acquired knowledge and skills or graduates' achieved results. This point of view is suitable to do international comparisons, demonstrate higher education achievements to the interested sides and create strategies of political development for higher education.

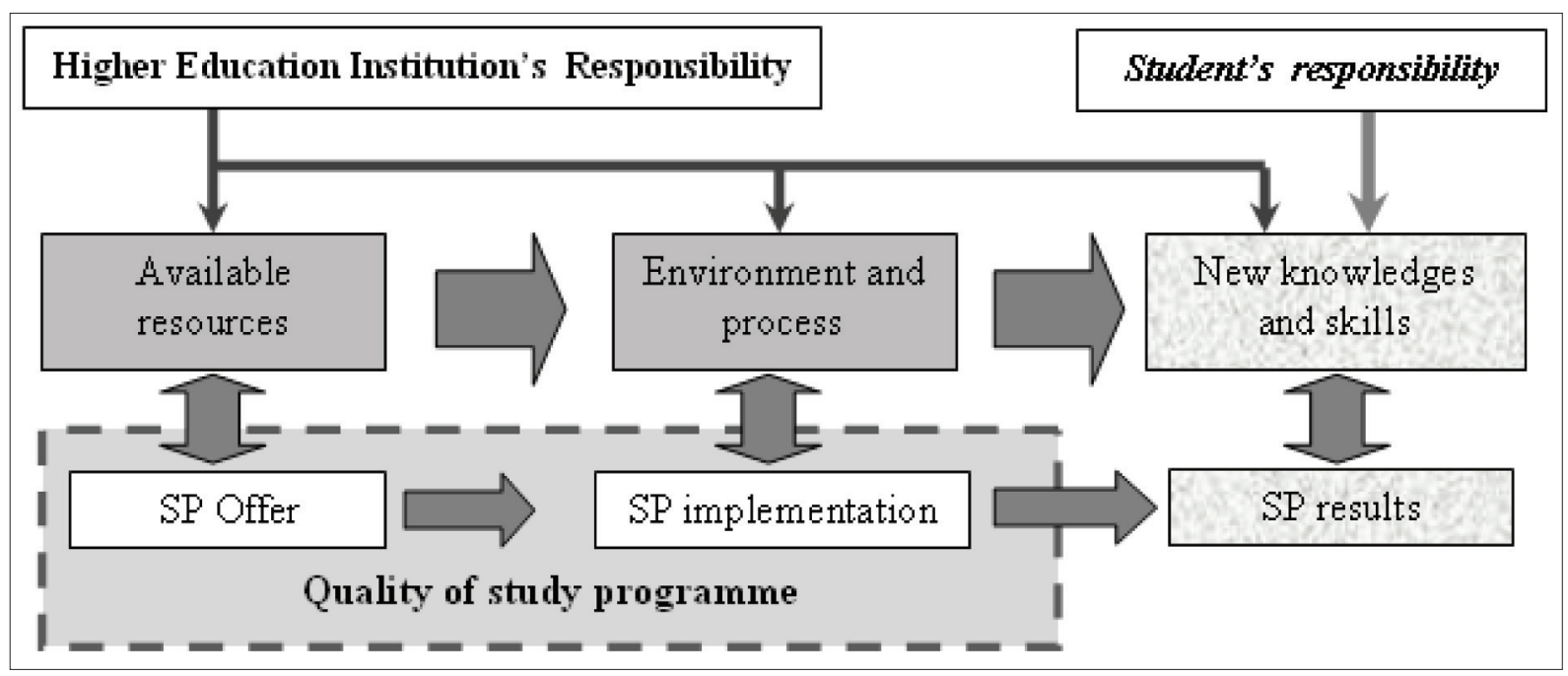

Figure 2. Components for study programme quality

Source: created by authors

However, to assess the quality of study programme it is important to stand apart from assessments, which do not refer directly to its quality. For example, it is practically impossible to assess how big study programme input is in student's newly acquired knowledge and skills or achieved results. They are formed from the one side mutually cooperating the study programme offer and implementation, but from the other side the student himself by getting involved into study process, they are also affected by many different factors outside studies. Therefore high study results not always testify of qualitative study programme, and vice versa. Together with this the quality of students' study results is not just the responsibility of higher education establishment; it is also students' co-responsibility (see Figure 2). Students' achievements in studies and outside them are not directly referred to study programme quality. Also, just after the study programme 
completion the results acquired in studies the usage of them is hard to identify, because it is necessary to have real practice during several years to assess the usefulness and usability of study results. Taking into account the mentioned above, for the experts' assessment initially there were offered 24 criteria which characterize study programme offer quality and study programme implementation quality.

The research uses AHP method which is a systematic procedure to arrange elements of any problem in hierarchy. In the research, experts compare the criteria groups, criteria and assessment approaches mentioned above in pairs, using Relative importance scale, which allows transforming verbal information into numbers (Saaty, 2006: 73). Doing the calculations intended in AHP method and summarising the acquired results of expert survey, each of elements involved into hierarchy analysis is set a relative importance coefficient, which in its turn allows making a unite system of study programme quality assessment.

Study programme quality assessment structure is shown in Figure 3. As the highest aim of the research (Level 1) is set „the evaluation of study programme quality alternative assessment approaches”. Second level includes two groups of criteria which characterize study programme quality:

- criteria of study programme offer quality,

- criteria of study programme implementation quality.

Third level includes criteria of study programme quality (12 in each group), which were assessed by experts as well as the groups of criteria correspondingly to the aim set in Level one. Fourth level sets three study programme quality assessment alternatives which were assessed by experts regarding the criteria, criteria groups and the main aim of research.

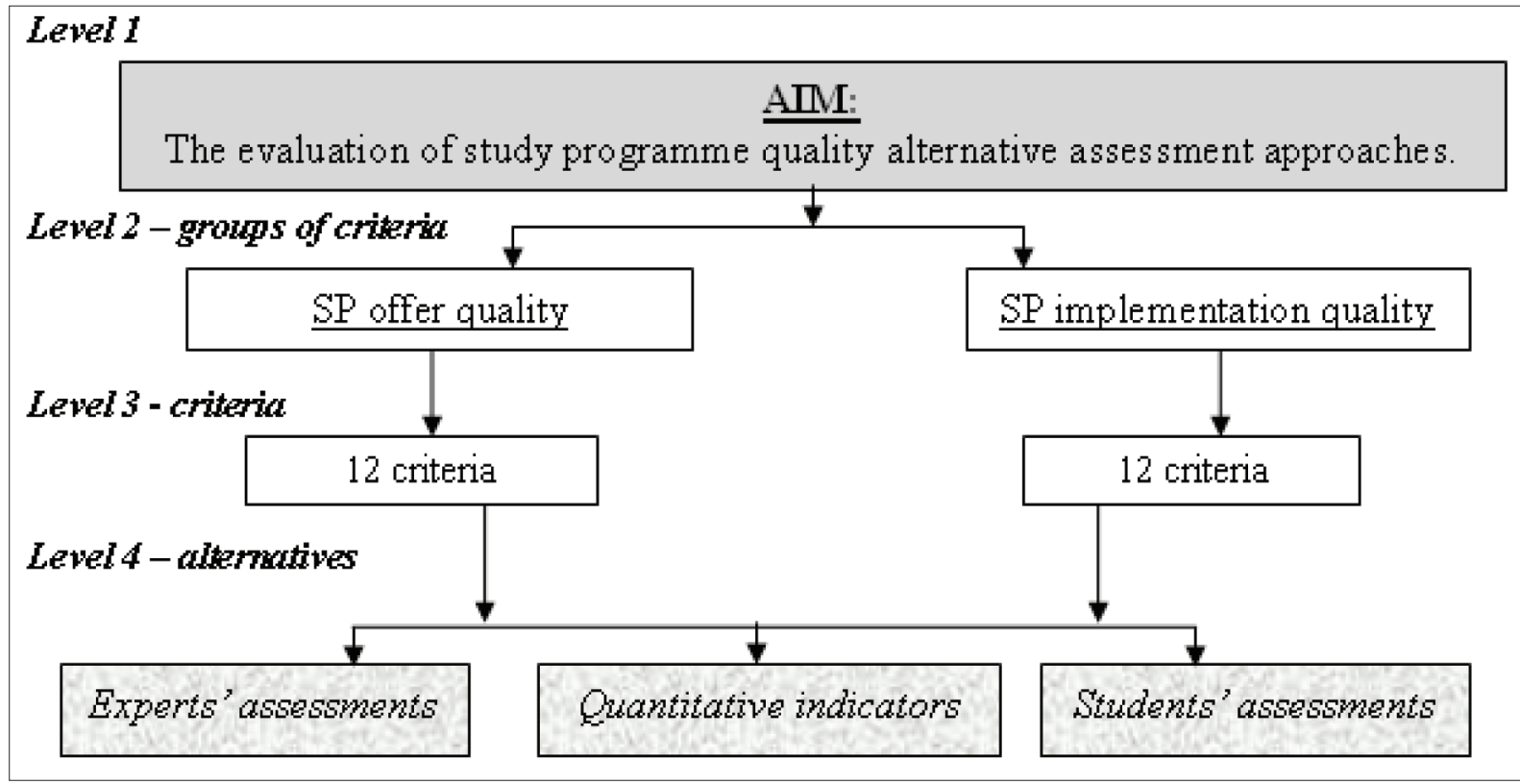

Figure 3. Structure for the AHP method

Source: created by authors

Initially the results of data analysis about the significance of criteria in study programme quality assessment were published in the international conference proceeding "New Challenges of Economic and Business Development - 2012", the publication "Investigation of the opportunities of study programme quality" (Līgotne, 2012: 382, 384-389). This article analyses in detail only the most important assessment criteria which were assessed by experts as the most significant for study programme offer and implementation quality assessment. 


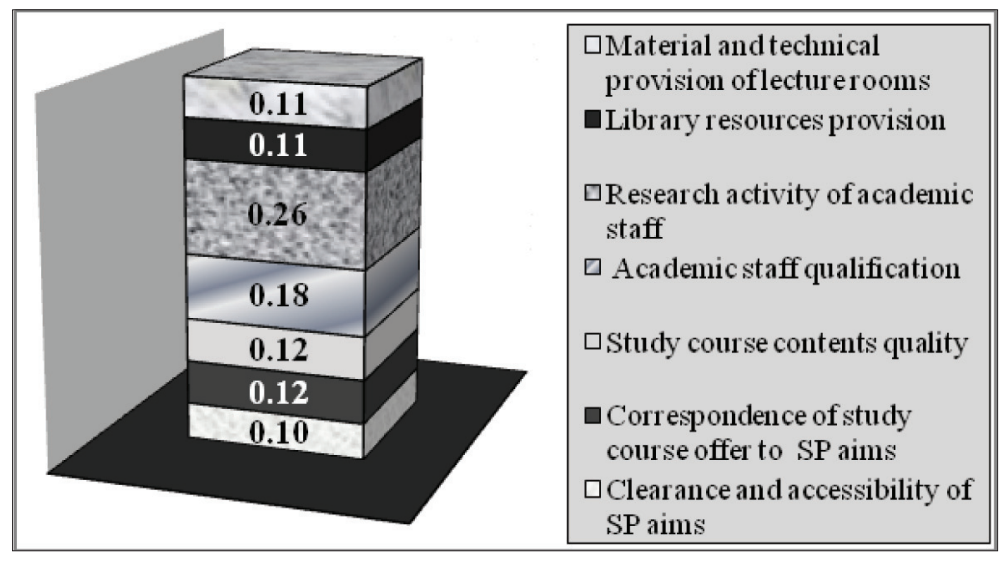

Figure 4. Criteria for SP Offer Quality

Source: created by authors

The quality of study programme offer is formed by study programme workout. Experts evaluated seven main criteria for quality of study programme (SP) offer:

1) clearance and accessibility of study programme aims;

2) correspondence of study course offer to study programme aims, that is, coordination of study course aims and results with study programme aims and results;

3) study course contents quality;

4) academic staff qualification, which is characterised by the position structure of academic staff involved in study programme, existence and correspondence of scientific degrees, length of service, as well as average age;

5) research activity of academic staff, which is characterised by publications and participation in conferences and projects;

6) library resources provision, which is characterised by literature sources and subscribed data bases;

7) material and technical provision of lecture rooms, including laboratory provision and accessibility of computers and internet.

Calculated relative significance for criteria of study programme offer quality is demonstrated in figure 4 . There can conduct, that Study programme offer quality is mainly characterized by qualitatively worked out study courses which correspond the study programme aims and correctly selected academic staff, which not only have necessary qualifications, but also actively continue to develop their knowledge and skills. Also important is the provision of library resources and material and technical provision in lecture rooms (Ligotne, 2012: 389).

The quality of study programme implementation is oriented to process to organize as high as possible study result achievement for students. Its main characterizer is education effectiveness, that is, in what amount a student acquires new knowledge, skills and values during the studies. Experts evaluated seven main criteria for quality of study programme implementation:

1) study course implementation, which is characterized by study course succession and connection, as well as provision of e-courses;

2) academic staff involvement in study process - average academic staff load in study programme, their accessibility to students, as well as academic staff cooperation with students;

3) studies give good basis of theoretical and practical knowledge, including research skills;

4) studies promote critical thinking; 
5) studies promote development of communication and generally used skills, which includes in itself working skills of written language, presentations, discussions and teamwork, as well as foreign languages, computer programming and organizational skills;

6) international experience in studies, which is characterized by students' mobility, guest lecturers and academic staff mobility;

7) students' satisfaction with the selected study programme.

Calculated relative significance for criteria of study programme implementation quality is demonstrated in figure 5.

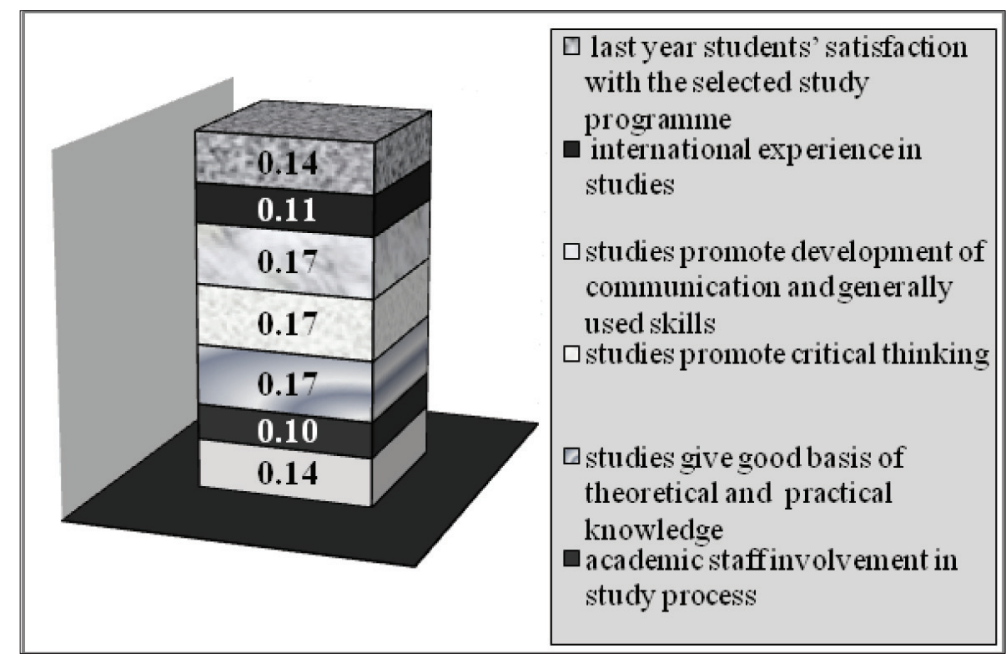

Figure 5. Criteria for SP Implementation Quality

Source: created by authors

There can conduct, that the most important thing in study programme implementation quality is not only to give good basis of theoretical and practical knowledge, but also to promote critical thinking and the development of communicative and generally used skills, which is not possible without qualitative study course contents and corresponding academic staff. That will promote students' satisfaction with the selected study programme (Līgotne, 2012: 389).

As study programme quality assessment alternatives are selected:

- Experts' assessments about higher education development, strengths and weaknesses, as well as opportunities and threats to work out suggestions in time and make decisions about the necessary improvements. This assessment alternative refers to higher education inner quality. The aim of experts' assessment is not to demonstrate higher education quality to the society, but to promote the continuous improvement of quality therefore providing the sustainability of higher education.

- Quantitative indicators are the most objective alternative of higher education quality assessment. Its aim is to compare and assess different higher education operation indicators, which mainly characterize the input and results. That way the society in clear and understandable way is shown higher education operation indicators which testify the quality.

- Students'assessments. Students' task is to assess if study process and its contents corresponds to their needs and aims. The aim of assessment is also to create and strengthen the feedback with one of the main interested sides in higher education therefore ensuring their involvement in quality improvement. 
Furthermore this article analyses the research results about the significance of the three quality assessment alternatives: experts' assessment, quantitative indicators and students' assessment. There are analyzed experts' survey assessments about the most significant approach for study programme quality assessment, as well as there are detected the most suitable ways of assessment for groups of criteria and for each criterion.

\section{The analysis of results acquired in research}

Evaluating study programme quality assessment alternatives for study programme on the whole and groups of criteria, we can see (see Figure 6), that as the most important both groups (higher education administrators and students) of experts have evaluated students' assessment. This way of assessment was assigned the relative importance coefficient 0.38 out of 1 . As the next most important study programme quality assessment alternative is evaluated experts' assessment with relative importance coefficient 0.32 , but quantitative indicators have been assessed with relative importance coefficient 0.3 .

However, we have to take into account that experts' assessments are not the same if compared within groups of criteria. In study programme offer quality assessment as the most important the experts have admitted experts' assessments and quantitative indicators, the relative importance coefficients being accordingly 0.37 and 0.36 . In its turn, as the most suitable alternative for study programme implementation quality the experts have admitted students' assessment, assigning it with relative importance coefficient 0.49 out of 1 .

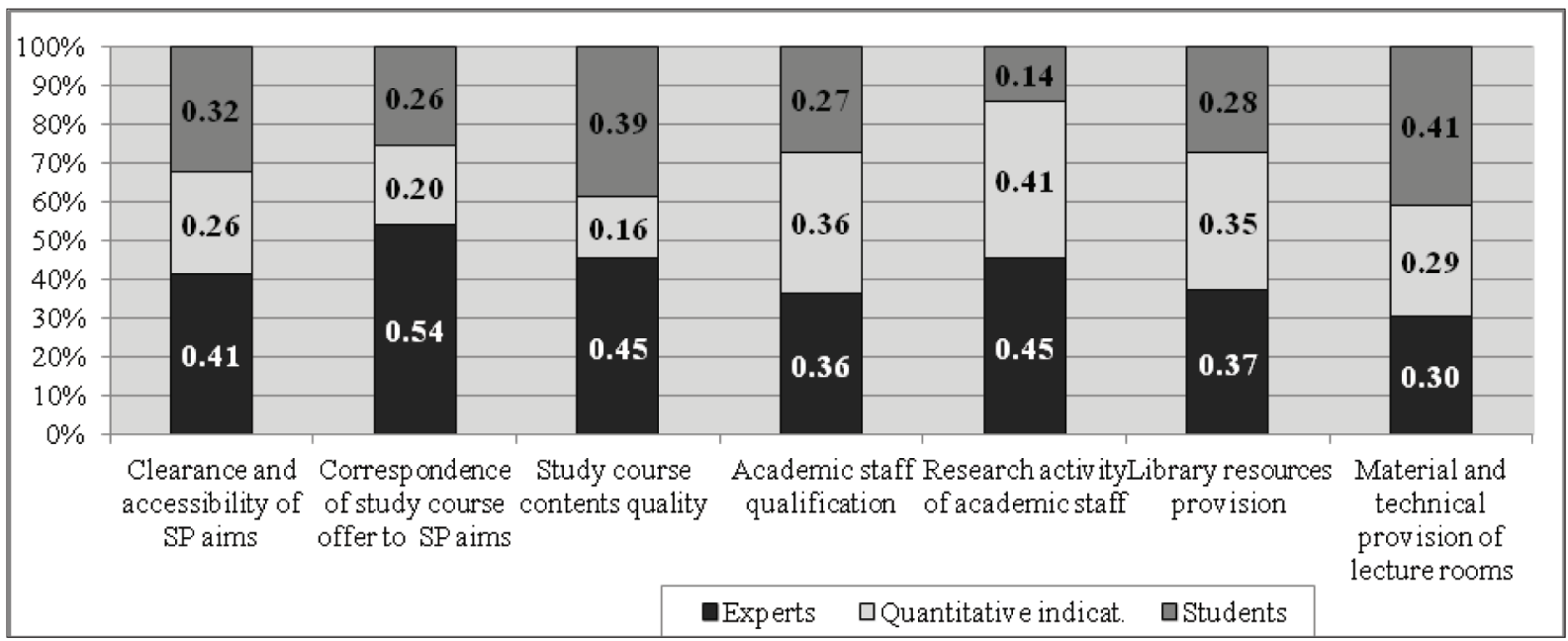

Figure 7. Assessments for evaluating approaches of SP offer quality

Source: created by authors

Evaluating study programme quality assessment alternatives for each criterion according to experts' assigned relative importance coefficients; we can state that each criterion can be appointed one or more ways which are most suitable for it. Figures 7 and 8 represent results of expert assessments for alternative approaches of study programme quality evaluating for every criteria. There are differences between expert assessments; relative importance coefficients for alternative assessment approaches are different to each criterion. In this case, it is useful to break down criteria in groups according to suitable assessment approach.

To evaluate the most suitable way of assessment for each criterion, there are evaluated experts' assigned relative importance coefficients. The evaluation of most suitable criteria is done in two stages: the first one evaluates the significance of relative importance coefficient according to Table 1, but the second detects the most suitable way of assessment. 


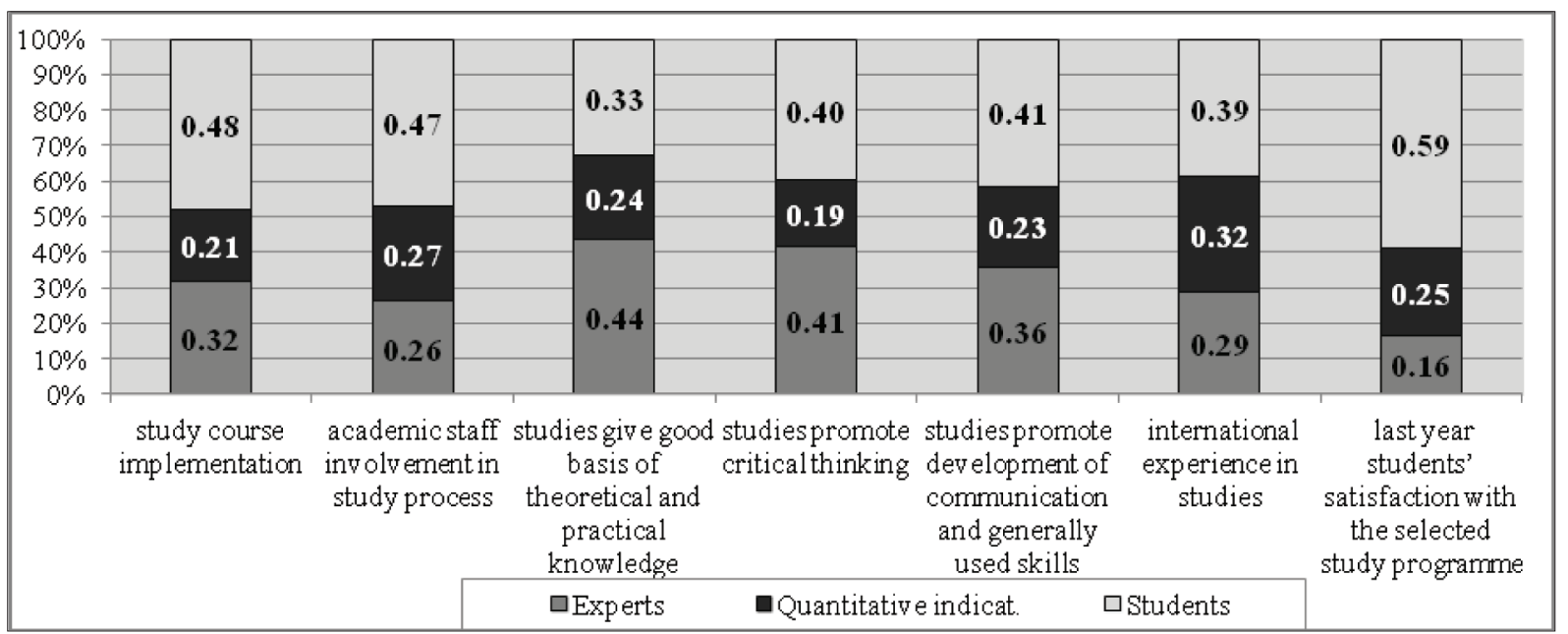

Figure 8. Assessments for evaluating approaches of SP implementation quality

Source: created by authors

Table 1. The relative significance coefficient division in groups

\begin{tabular}{|l|l|}
\hline \multicolumn{1}{|c|}{ Relative importance coefficient value } & \multicolumn{1}{c|}{ Characteristics } \\
\hline 0,55 and more & Main way of assessment, can be the only way of assessment \\
\hline $0,45-0,54$ & Very important way of assessment, can be independent \\
\hline $0,35-0,44$ & Important way of assessment \\
\hline $0,25-0,34$ & Partly important way of assessment, cannot be independent \\
\hline below 0,25 & Unimportant way of assessment, can be replaced \\
\hline
\end{tabular}

Source: made by authors

Study programme quality assessment criteria can be divided into seven groups according to their most suitable way of assessment, observing the following rules:

1) at least one of study programme quality assessment alternatives has got relative importance coefficient 0,35 ;

2) alternative assessment ways are summarized, if their relative importance coefficients are in neighboring groups.

Table 2. Groups of SP quality criteria according to suitable assessment approache

\begin{tabular}{|l|l|}
\hline \multicolumn{1}{|c|}{ Charasteristic of group } & \multicolumn{1}{c|}{ Criteria of SP quality } \\
\hline Group 1 experts' assessments & Correspondence of study course offer to SP aims \\
\hline Group 2 quantitative indicators & - \\
\hline Group 3 students' assessments & $\begin{array}{l}\text { Study course implementation } \\
\text { Academic staff involvement in study process } \\
\text { Students' satisfaction with the selected SP }\end{array}$ \\
\hline $\begin{array}{l}\text { Group } 4 \text { experts' assessments and } \\
\text { quantitative indicators }\end{array}$ & $\begin{array}{l}\text { Research activity of academic staff } \\
\text { Library resources provision }\end{array}$ \\
\hline $\begin{array}{l}\text { Group } 5 \text { experts' assessments and students } \\
\text { assessments }\end{array}$ & $\begin{array}{l}\text { Study course contents quality } \\
\text { Studies give good basis of theoretical and practical knowledge } \\
\text { Studies promote critical thinking }\end{array}$ \\
& \begin{tabular}{l} 
Studies promote development of communication and generally used skills \\
\hline
\end{tabular} \\
\hline
\end{tabular}




\begin{tabular}{|l|l|}
\hline \multicolumn{1}{|c|}{ Charasteristic of group } & \multicolumn{1}{c|}{ Criteria of SP quality } \\
\hline $\begin{array}{l}\text { Group } 6 \text { students' assessments and } \\
\text { quantitative indicators }\end{array}$ & - \\
\hline $\begin{array}{l}\text { Group 7 experts' and students' assessments } \\
\text { and quantitative indicators }\end{array}$ & $\begin{array}{l}\text { Material and technical provision of lecture rooms } \\
\text { Clearance and accessibility of SP aims }\end{array}$ \\
& $\begin{array}{l}\text { Academic staff qualification } \\
\text { International experience in studies }\end{array}$ \\
\hline
\end{tabular}

Source: made by authors

Evaluating study programme quality assessment alternatives for each criterion, we can conclude that to assess the study programme offer and implementation quality, it is necessary to use all three ways of assessment. Taking into account the research results (see Table 2), we can conclude that

- Experts'assessment has the main meaning in study programme offer quality assessment. It can be the only way of assessment when evaluating the study course correspondence to study programme aims. It can also be combined with quantitative indicators when assessing the research achievements of academic staff or library resource provision;

- Quantitative indicators cannot be independent way of assessment. They can be added to experts' assessments, but not students' assessments;

- Students' assessments main importance is in study programme implementation quality assessment. It can be the only assessment when evaluating study course implementation, academic staff involvement in study process and students' satisfaction with study programme on the whole.

For some assessment criteria, none of the assessment ways appeared as the main (see Group 7 in Table 2) or all three assessment ways are equally important and necessary. Such criteria are: material technical provision of rooms, clearance and attainability of study programme aims, academic staff qualification and international experience.

Basing on the results acquired in the research, we can distinguish five groups of criteria according to their approach for assessment. Although the number of groups has decreased, none of the three study programme quality assessment approaches is excluded. Therefore, to assess the study programme quality it is necessary to use both expert and student assessments and quantitative indicators. It allows concentrating not only on the aims of interested sides in higher education and good quantitative indicators, but also on inner quality provision. It is important to prove the reasonable usage of the resources invested into higher education and to ensure sustainability of higher education.

The results of this research should be taken into account when organizing study programme quality assessment, selecting the appropriate assessment criteria and the approaches for their assessment.

\section{Conclusions}

1. Studying the literature about higher education quality, we can identify several problems which complicate the definition of the notion "higher education quality". It creates different perceptions of higher education quality which differ in wideness and purpose.

2. The higher education quality assessment methodology worked out in research intends to use as foundation three quality assessment conceptions distinguished by R. Barnett: objective conception, subjective conception and development conception. Each of these conceptions in study programme quality assessment intends to use different alternative assessment approaches: experts' assessment, quantitative indicators and students' assessment of study programme.

3. Approbating the worked out higher education quality assessment methodology, we can conclude that the AHP method is suitable for solving such complicated problems. Method allows evaluating study 
programme assessment alternatives, determining their significance in assessment of separate criteria, groups of criteria and study programme quality.

4. For full assessment of higher education quality we must use all R. Barnett's higher education assessment conceptions. It allows concentrating not only on aims of interested sides in higher education and on good quantitative indicators, but also on inner quality provision. It is necessary to prove the reasonable usage of invested resources in higher education and ensure sustainability of higher education.

5. Assessing the three assessment approaches detected in research, we can conclude that for study programme quality assessment it is necessary to use all three quality assessment alternatives. However, as the most important both experts groups have admitted students' assessment approach.

6. Assessing quality assessment alternatives within criteria groups and for separate criteria, we can state common tendencies. In study programme offer quality assessment the most important and suitable is experts' assessment approach. For evaluation of separate SP offer criteria, experts' assessment should be added by quantitative indicators. In its turn, the most important one for study programme implementation quality criteria assessment is students' assessment approach.

\title{
References
}

Ball, C. (1985). Fitness for Purpose. Essays in Higher Education. Edited by D. Urwin. Guildford. SRHE and NFERNelson, $143 \mathrm{p}$.

Barnet, $R$. (1992). Improving higher education: total quality care. SRHE and Open University Press, 238 p.

Briška, A. (2010). "Quality" of study programmes in higher education. International conference. Website: http://www. ev.lu.lv/conf2010/index.php?Conference_Proceedings. „New Socio-economic Challenges of Development in Europe - 2010" proceedings. Riga: University of Latvia, p. 128-134.

Giertz, B. (2000). The Qaulity concept in Higher education. Website: http://web.blweb.it/esoe/tqmhe2/23.pdf. Sinergie Rapporti di Ricerca, No. 9, p. 295-306.

Harvey, L., Green, D. (1993). Defining quality. Website: http://www.scribd.com/doc/39175910/Defining-Quality. Assessment and Evaluation in Higher Education, Vol. 18, 26 p. London.

Lịgotne, A. (2012). Investigation of the opportunities of study programme quality. Website: http://www.evf.lu.lv/ conf2012/proceedings. International conference „New Challenges of Economic and Business Development - 2012” proceedings. Riga: University of Latvia, p. 377-390.

Polanyi, M. (1966). The Tacit Dimension. Doubleday \& Company Inc., Garden City, New York.

Rauhvargers, A. (2011). EUA Report in Rankings 2011: Global University Rankings and Their Impact. Website: http:// www.eua.be/Libraries/Publications_homepage_list/Global_University_Rankings_and_Their_Impact.sflb.ashx. European University Association, $85 \mathrm{p}$.

Saaty, T. L. (2006). Fundamentals of Decision Making and Priority Theory with the Analytic Hierarchy Process, Vol. 6 of the AHP series. USA, $478 \mathrm{p}$.

Storen, L. A., Aamodt, P. O. (2010). The Quality of Higher Education and Employability of graduates. Quality in Higher Education, Vol. 16, No. 3, November, p. 297-313.

Van Vught, F. (1997). To innovate for quality. Quality assurance as support for processes of innovation. The Swedish model in Comparative Perspective. Stockholm: Høgskoleverkets Skriftserie.

\section{AUKŠTESNIOJO MOKSLO STUDIJU PROGRAMU KOKYBÉS VERTINIMAS}

\author{
Liudmila Bandeviča, Agnese Līgotne
}

Latvijos universitetas (Latvija)

\section{Santrauka}

Studijų programos kokybės vertinimas prisideda prie aukštesniojo mokslo studijų kokybės, kuri savo ruožtu yra viena esminių ekonomikos vystymosi prielaidų. Šiuo metu visuomenejje nemažai diskutuoja- 
ma, kas yra ta aukštesniojo mokslo kokybė ir kaip ją i̇vertinti. Pragmatinė prieiga skatina nustatyti studijų kokybės vertinimo kriterijus, bet pirmiausia reikia suprasti, kas yra ta aukštesniojo mokslo kokybė. Laikui bėgant susiformavo kelios aukštesniojo mokslo kokybės sampratos. Kadangi jos skiriasi, reikia ir skirtingos kokybės vertinimo prieigos.

Siekiant sukurti metodologini aukštesniojo mokslo kokybės vertinimo pagrindą remtasi R. Barnett išskirtomis aukštesniojo mokslo kokybės vertinimo koncepcijomis: objektyvia, subjektyvia ir plètros. Kiekviena koncepcija siūlo skirtingas aukštesniojo mokslo kokybès vertinimo prieigas.

Atliekant tyrimą taikytas analitinès hierarchijos proceso (AHP) metodas, siekiant nustatyti svarbiausius studijų programų kokybès kriterijus ir tinkamiausius jų vertinimo būdus. AHP metodas remiasi ekspertų apklausa, kurioje dalyvavo dvi svarbiausios aukštesniojo mokslo plètra suinteresuotos grupès: aukštesniojo mokslo administracinis personalas ir studentai. Aukštesniojo mokslo administratoriui atstovavo Aukštesniojo mokslo komiteto atstovai, Latvijos universiteto skyrių vadovai ir vadovai, susiję su studijų programos kokybės vertinimu bei programų akreditavimu. Tuo tarpu studentams atstovavo Latvijos studentu sajungos atstovai, Latvijos universiteto Studentų tarybos atstovai ir įvairių Latvijos universiteto fakultetų studentai.

PAGRINDINIAI ŽODŽIAI: studiju programu kokybè, kokybès vertinimas, kokybès vertinimo metodologija, vertinimo kriterijai, kokybès vertinimo prieigos, analitinès hierarchijos proceso metodas.

JEL KLASIFIKACIJA: I230, I210, D790 